\title{
Penerapan Metode Waterfall Pada Sistem Informasi Perpustakaan Desa Pebayuran Kabupaten Bekasi
}

\author{
Muhamad Tabrani $^{1}$, Abdussomad $^{2}$, Robi Sopandi ${ }^{3}$ \\ Email : Muhammad.mtb@bsi.ac.id ${ }^{1}$, abdussomad.bdu@bsi.ac.id ${ }^{2}$, robi.rbs@nusamandiri.ac.id ${ }^{3}$ \\ Sistem Informasi, Fakultas Teknologi Informasi, Universitas Bina Sarana Informatika ${ }^{1,2}$ \\ Teknik Informatika, STMIK Nusa Mandiri Jakarta ${ }^{3}$
}

\begin{abstract}
Abstrak
Perpustakaan sebagai bagian dari lembaga pendidikan dituntut untuk menyediakan segala sumber informasi yang dibutuhkan dalam proses belajar mengajar. Untuk meningkatkan layanan sumber informasi di perpustakaan dibutuhkan sistem informasi agar pelayanan lebih efektif dan efisien. Tidak hanya pendidikan saat ini beberapa desa sudah memiliki perpustakaan desa salah satunya desa Karang Harus kabupaten Bekasi. Perpustakaan desa Pebayuran merupakan fasilitas yang diberikan oleh pemerintah tingkat desa guna mendukung proses belajar serta mendapatkan pengetahuan umum lebih bagi masyarakat desa khususnya DesaPebayuran. Saat ini proses berjalan di perpustakaan pengolahan data mulai dari pendaftaran keanggotaan, transaksi peminjaman serta pengembalian buku masih dilakukan secara manual sehingga proses pendaftaran membutuhkan waktu dalam registrasi anggota baru serta proses pencarian data anggota yang lama, pada proses peminjaman dan pengembalian juga masih dilakukan secara manual sehingga seringkali terjadi manipulasi data yang mengakibatkan buku yang tersedia di catatan tidak sesuai dengan buku yang ada di perpustakaan. Untuk meminimalisir kendala pada perpustakaan daerah diperlukanya sistem informasi yang terkomputerisasi, Sehingga dalam pengelolaan perpustakaan lebih efektif dan efisien. Dalam pengembangan sistem informasi perpustakaan penulis menggunakan metode waterfall dengan mengimplementasikan metode waterfall dapat memudahkan perancangan website perpustakaan mengingat metode terdiri dari proses analisis, desain, pengkodean, pengujian sehingga mempermudahkan dalam proses pembuatan dan proses pengawasan sampai dengan proses pengimplemantasian website perpustakaan desa Pebayuran.
\end{abstract}

Kata Kunci: Sistem Informasi, perpustakaan, waterfall

\section{PENDAHULUAN}

Di era perkembangan Sistem informasi saat ini ilmu pengetahuan tidak hanya diperoleh dari pendidikan saja akan tetapi dapat diperperolah dengan menggunakan media secara online yang saat ini sedang berkembang pesat. akan tetapi salah satu media ilmu pengetahuan yang paling mudah dan tanpa biaya saat ini dapat di akses tersedia di perpustakaan. Perpustakaan merupakan unit kerja dari suatu badan atau lembaga tertentu yang mengelola bahan-bahan pustaka. Baik berupa buku maupun non buku yang diatur secara sistematis menurut aturan tertentu sehingga dapat digunakan sebagai sumber informasi[1]. Sesuai dengan pengertian perpustakaan memiliki fungsi sebagai tempat yaitu sebagai sarana dalam penyimpanan, mengolah, menyajikan, menyebarluaskan, dan melestarikan pengetahuan.

Pada Desa Pebayuran untuk meningkatkan minat belajar khususnya membaca masyarakat desa telah berdiri perpustakaan Perpustakaan Desa Pebayuran, yang merupakan perpustakaan yang merupakanperpustakaanerangkat Desa Pebayuran yangsengajadibuatolehperangkat
DesaPebayuranyangbertujuanuntukMendoron gminatbacawargamasyarakatSaat ini proses berjalan di perpustakaan pengolahan data mulai dari pendaftaran keanggotaan, transaksi peminjaman serta pengembalian buku masih dilakukan secara manual sehingga proses pendaftaran membutuhkan waktu dalam registrasi anggota baru serta proses pencarian data anggota yang lama, pada proses peminjaman dan pengembalian juga masih dilakukan secara manual sehingga seringkali terjadi manipulasi data yang mengakibatkan buku yang tersedia di catatan tidak sesuai dengan buku yang ada di perpustakaan. Untuk meminimalisir kendala pada perpustakaan daerah diperlukanya sistem informasi yang terkomputerisasi, Sehingga dalam pengelolaan perpustakaan lebih efektif dan efisien.

Sistem Informasi yang akan dibuat dalam mendukung perpustakaan adalah dimulai dari halaman login untuk admin ataupun halaman login untuk anggota, halaman pendaftaran anggota, halaman databuku, halaman riwayat peminjaman dan pengembalian data buku, sampai dengan informasi yang berhubungan laporan peminjaman buku di perpustakaan. 


\section{Metode Penelitian}

A. Metode Pengumpulan Data

Dalam penelitian penulis menggunakan teknik pengumpulan data yang nantinya digunakan dalam pengembangan sistem informasi perpustakaan desa Pebayuran Kabupaten Karawang:

1) Metode Observasi

Pada proses ini penulis melakukan pengamatan secara tidak langsung terhadap objek yang nantinya dijadikan penelitian dalam hal ini perpustakaan, sehingga informasi tentang perpustakaan yang menjadi objek penelitian kami mendapatkan informasi yang jelas dan akurat yang nantinya diperlukan dalam pengembangan sistem informasi.

2) Metode Wawancara

Pada proses ini penulis melakukan proses tanya jawab langsung kepada para narasumber terutama pimpinan perpustakaan serta pustakawan agar dapat melengkapi data yang didapat dalam proses observasi serta menyakinkan penulis bahwa permasalah yang didapat oleh penulis sesuai dengan permasalah yang terjadi pada tempat riset serta bertanya pada orang yang tepat.

3) Metode Studi Pustaka

Untuk melengkapi penelitian diperlukannya dipelukan metode studi pustaka dengan menggunakan buku-buku referensi, jurnal ilmiah serta laporan yang berkaitan dengan permasalahan serta judul yang akan diambil sebagai referensi.

\section{B. Metode Pengembangan Perangkat Lunak}

Menurut Menurut Rosa dan Shalahuddin dalam jurnal[2] Siklus hidup pengembangan sistem (System Development Life CycleSDLC) metode pendekatan sistem bagi pengembangan suatu sistem informasi, atau metode air terjun (waterfall) sering juga disebut model sekuensial linier (sequential linear) atau alur hidup klasik (classic life cycle). Metode waterfall melakukan pendekatan alur hidup perangkat lunak secara sekuensial atau terurut dimana model pada umumnya dimulai dari Analisa, desain, pengkodean, pengujian, dan tahap pendukung.

Menurut Sukamto dalam jurnal[3] "Model $S D L C$ air terjun (waterfall) sering juga disebut model sekuensial linier (sequential linear) atau alur hidup klasik (classic life cycle)"

Berikut ini penggambaran metode waterfall:

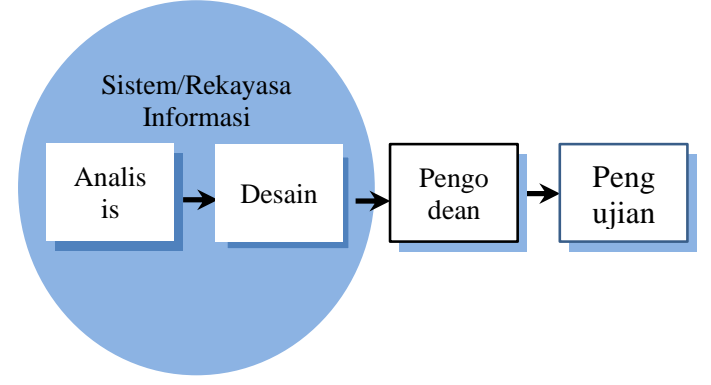

Sumber Rosa dan Shalahuddin dalam jurnal [2] Gambar I . Model Waterfall.

1) Analisis kebutuhan perangkat lunak

Analisa kebutuhan dilakukan untuk mendapatkan informasi, model serta spesifikasi yang sesuai yang dibutuhkan oleh user atau pengguna. Proses pengumpulan kebutuhan dilakukan secara baik agar nantinya sesuai dengan kebutuhan dari user. Dalam analisa perangkat lunak baik user atau mendesain perangkat lunak harus terlibat aktif dalam tahap ini, informasi-informasi dari user sangat bermanfaat serta menjadi acuan dalam desain perangkat lunak.

2) Desain perangkat lunak

Pada tahap Desain perangkat beberapa proses yang akan dilaksanakan dalam proses ini tidak hanya berfokus kepada desain pembuatan perangkat lunak, desain struktur data, arsitektur dari perangkat lunak yang akan digunakan, tampilan representasi antarmuka dan pengkodean yang akan digunakan, pada proses ini juga mentranslasi kebutuhan perangkat lunak untuk membuatkan program.

3) Pembuatan Kode Program

Setelah proses desain masuk ke tahap melakukan coding atau implementasi desain antar muka kedalam program, pada tahapan ini dilakukan juga proses testing dan melakukan perbaikan kode program yang error, mengingat pada saat proses penulisan kode program biasanya kita akan mendapati beberapa kendala kode program error. Proses penulisan kode program dibutuhkan ketelitian yang sangat baik oleh programer

4) Pengujian

Pada tahapan berfokus pada perangkat lunak diuji secara fungsional serta logik, serta memastikan setiap bagian sudah berfungsi sesuai dengan desain antarmuka, hal tersebut dilakukan untuk meminimalisir kesalahan yang akan terjadi pada penggunaanya serta menghasilkan keluaran sesuai dengan yang diinginkan. 


\section{Landasan Teori}

1) Pengertian Sistem

Kata Sistem berasal dari Bahasa latinsystmaēma) dan bahasa Yunanisustmaēma) yang memiliki arti satu kesatuan yang memiliki komponen yang saling terhubung untuk memudahkan aliran informasi, dalam bahasa sederhana sistem dapat diartikan suatu kumpulan atau himpunan yang terdiri dari komponen, unsur atau variabel yang saling terorganisir, saling berinteraksi dan saling ketergantungan antara satu dengan yang lain.

Sistem adalah kumpulan/group dari sub sistem/bagian/komponen apapun baik fisik maupun non fisik yang saling berhubungan satu sama lain dan bekerja sama secara harmonis untuk mencapai tujuan tertentu[4].

Menurut al fatta dalam[5] bahwa sistem merupakan sekelompok dari dua atau lebih subsistem, sekumpulan objek-objek yang saling berelasi dan berinteraksi serta berhubungan antar objek sebagai satu kesatuan yang dirancang untuk mencapai satu tujuan.

2) Sistem Informasi

Sistem memiliki manfaat untuk dapat menghasilkan informasi yang nantinya informasi tersebut dapat menjadi dasar pengambil keputusan serta pertimbangan untuk mencapai tujuan dalam sebuah organisasi atau perusahaan.

Sistem informasi merupakan gabungan dari empat bagian utama diantaranya mencakup perangkat lunak, perangkat keras, infrastruktur dan sumber daya manusia (SDM) yang terlatih. Bagian-bagian ini saling berkaitan untuk menciptakan sistem yang mengolah data menjadi informasi yang bermanfaat[5].

Menurut kadir dalam[4] "Sistem informasi adalah sebuah rangkaian prosedur formal dimana data dikelompokkan, diproses menjadi informasi, dan didistribusikan kepada pemakai"

3) Sistem Informasi Perpustakaan

Perpustakaan merupakan bagian dari lembaga pendidikan yang diharapkan dapat menyediakan segala informasi di bidang bidang ilmu pengetahuan baik di lembaga pendidikan maupun di masyarakat.

Sistem informasi perpustakaan didefinisikan sebagai seperangkat aturan atau elemen yang berada dalam organisasi yang digunakan untuk memenuhi kebutuhan yang ada pada perpustakaan. Sistem informasi terdiri dari lima komponen yaitu

hardware

(perangkat keras

), software

(perangkat lunak), data, prosedur, dan manusia [6].

\section{HASIL DAN PEMBAHASAN}

A. Prosedur Sistem Berjalan

Prosedur berjalan merupakan tahapan kegiatan yang saat ini sedang berjalan pada perpustakaan atau rutinitas perpustakaan saat ini. Adapun prosedur berjalan perpustakaan Desa Pebayuran sebagai berikut:

1) Pendaftaran Kartu Anggota Baru

Proses berjalan pendaftaran anggota mendatangi langsung perpustakaan desa Pebayuran, kemudian calon anggota diberikan formulir keanggotaan untuk diisi, setelah semua data di formulir dilengkapi, calon anggota menyerahkan formulir isi tersebut ke petugas perpustakaan dan menjadi dasar diterbitkannya kartu anggota perpustakaan.

2) Proses Peminjaman dan Pengembalian Buku

Proses Peminjaman buku setiap masyarakat yang akan meminjam buku wajib menjadi anggota dengan menyerahkan kartu anggota perpustakaan pada saat melakukan peminjaman dan pengembalian buku perpustakaan.

\section{3) Pembuatan Laporan}

Petugas perpustakaan setiap mencatat data peminjaman dan pengembalian yang dilakukan oleh masing-masing anggota sesuai kesepakatan oleh anggota yang meminjam buku.

Jika dilihat diri prosedur berjalan perpustakaan desa Pebayuran masih menggunakan pencatatan manual pada proses peminjaman dan pengembalian buku, sehingga sangat memungkinkan sekali mengalami kesalahan pencatatan bahkan sampai lupa melakukan pencatatan sehingga beberapa buku mengalami kehilangan setiap tahunnya karena pada saat peminjaman tidak tercatat.

Diperlukan penyajian sistem informasi berbasis komputer dalam bentuk web agar informasi dapat lebih mudah di akses dan di simpan ke database. Perlu adanya sistem yang telah terkomputerisasi agar peminjaman, pengembalian dan pembuatan laporan peminjaman dan pengembalian buku lebih cepat. Penggunaan database mengurangi resiko 
kehilangan data penting serta menghasilkan informasi lebih akurat dan tepat waktu.

\section{B. Perancangan Sistem Informasi}

1) Kebutuhan Pengguna

Pada aplikasi Perpustakaan Desa Pebayuran memiliki dua pengguna yang saling berinteraksi dalam lingkungan sistem yaitu: Admin dan Anggota Kedua pengguna tersebut memiliki karakteristik interaksi dengan sistem yang berbeda-beda dan memiliki kebutuhan informasi yang berbeda-beda, sebagai berikut :

a. Skenario Kebutuhan Admin
1) Melakukan Login
2) Mengelola Menu master Admin
3) Mengelola Data Buku
4) Mengelola Data Detail Buku
5) Mengelola Data Kategori buka
6) Mengelola Data peminjaman Buku
7) Mengelola Data Pengembalian Buku
8) Laporan data Buku
9) Laporan data Anggota

b. Skenario Kebutuhan Anggota

1) Melakukan Login

2) Melakukan Pendaftaran anggota

3) Beranda Anggota

4) Data Buku

5) Melakukan Pinjaman

6) Melakukan Pengembalian

7) Melakukan Logout

2) Kebutuhan Sistem

a. Pengguna harus melakukan login terlebih dahulu untuk dapat mengakses aplikasi dengan menginput username dan password agar privasi dari pengguna masing-masing dapat terjaga keamanannya.

b. Pengguna harus melakukan logout setelah selesai menggunakan aplikasi.

c. Diagram Use Case Sistem Informasi

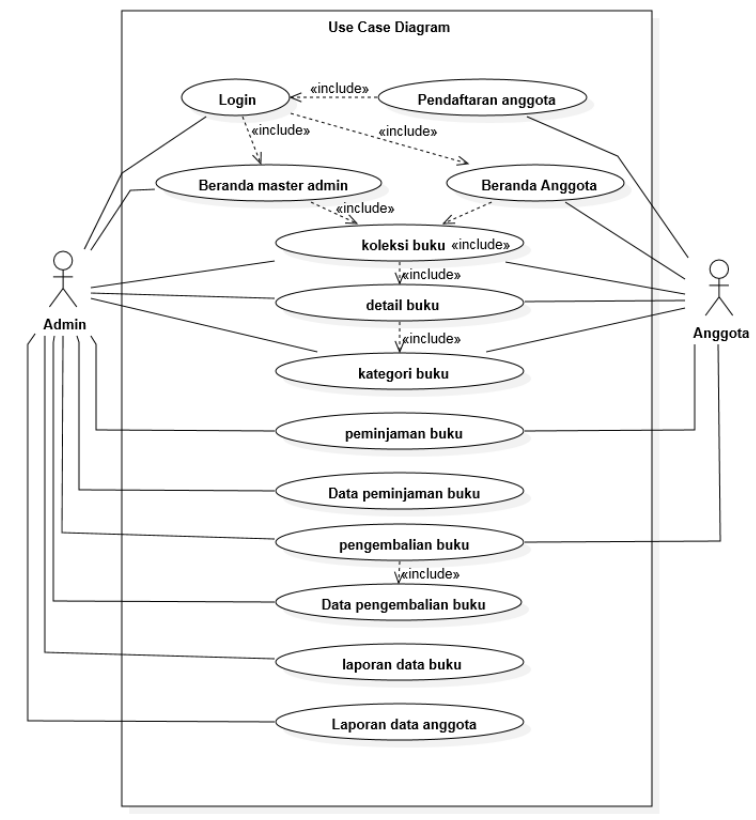

Gambar 2. Diagram Use Case Sistem

d. Activity Diagram Sistem

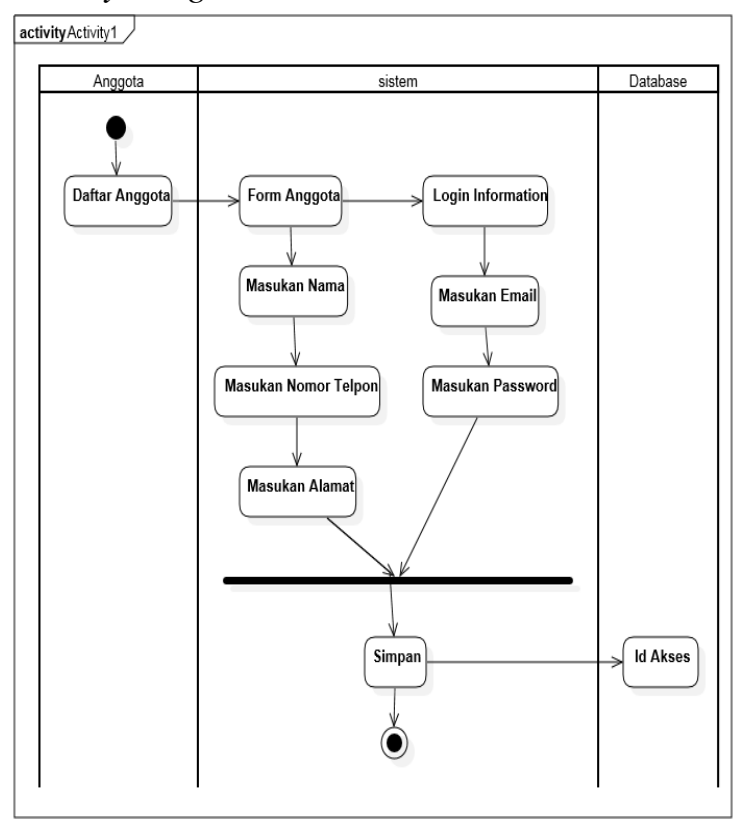

Gambar 3. Activity Diagram Sistem 
e. Entity Relationship Diagram

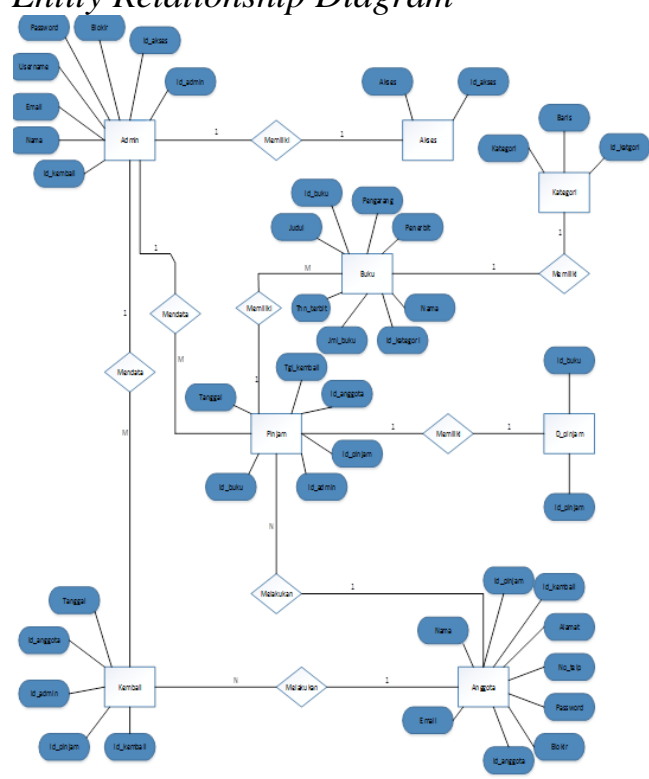

Gambar 4. ERD Sistem Informasi

f. Logical Record Structured Sistem

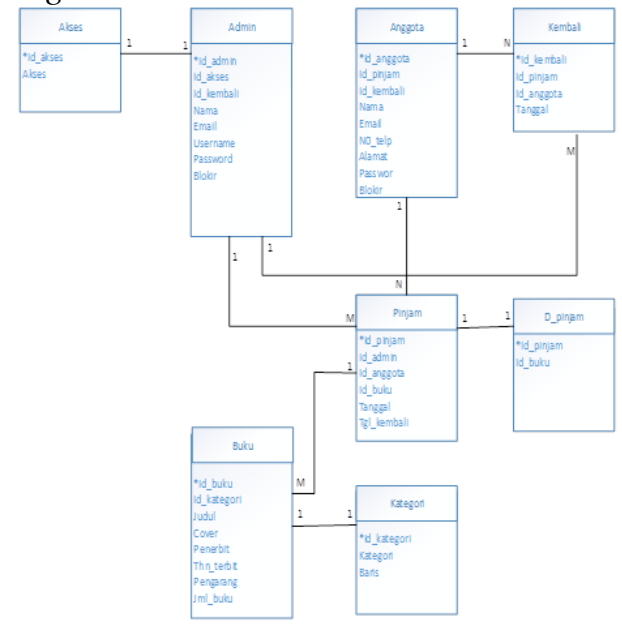

Gambar 5. LRS Sistem

g. Class Diagram Sistem Usulan

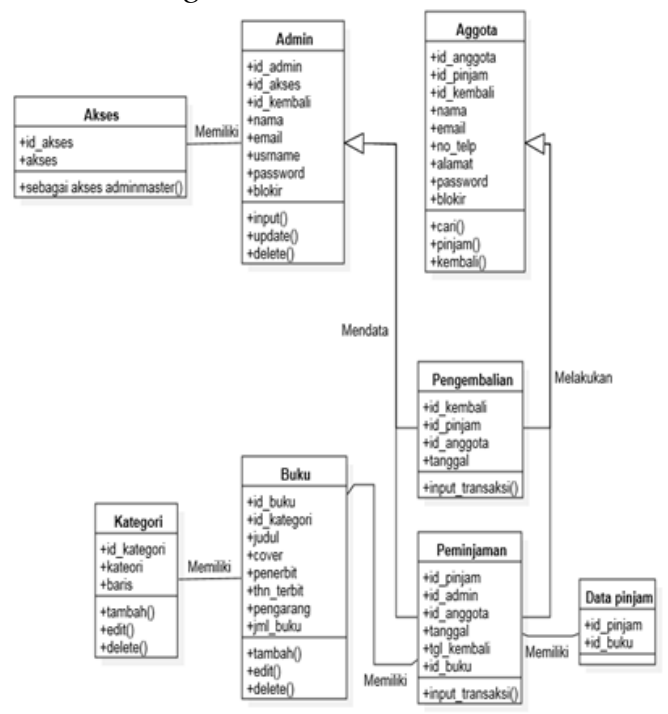

Gambar 6. Class Diagram Sistem

\section{Rancangan prototype Sistem Informasi Perpustakaan}

1) Rancangan Tampilan Menu Login.

Pada halaman ini admin diminta memasukan user dan password untuk dapat masuk ke halaman administrator

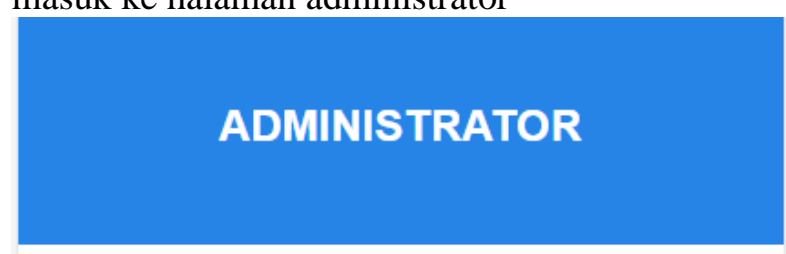

admin

\section{$\log \ln$}

Gambar 7. Tampilan Menu Login

2) Tampilan Edit Admin

Pada bagian hal ini administrator dapat menambah dan mengedit administrator
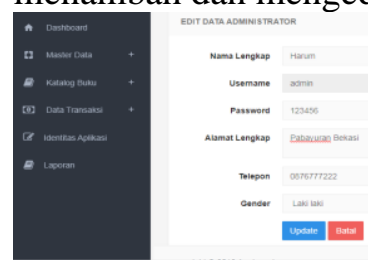

Gambar 8. Tampilan edit Admin

3) Tampilan Katalog Buku

Halaman ini digunakan untuk menambah, mengedit, hapus, data buku yang ada pada perpustakaan desa Pebayuran

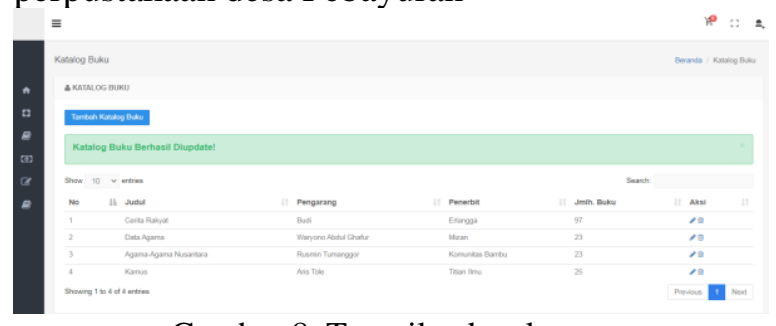

Gambar 8. Tampilan katalog

4) Rancangan tampilan Peminjaman buku Halaman ini digunakan untuk menginputkan data pinjaman mulai dari nama anggota, judul buku sampai dengan tanggal pinjam dan tanggal kembali. 


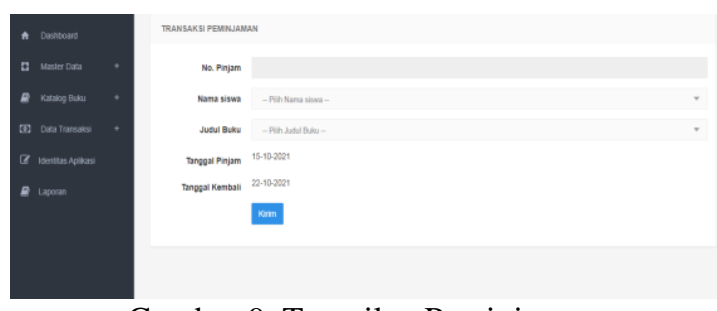

Gambar 9. Tampilan Peminjaman

5) Tampilan Laporan

Halaman ini digunakan untuk menampilkan semua data baik itu data anggota, data buku ataupun data peminjaman, pencarian juga dapat dilakukan berdasarkan, pertanggal, perbulan dan pertahun

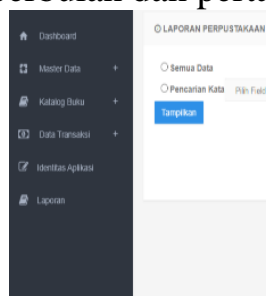

Gambar 12. Tampilan Menu Laporan Bulanan

\section{Kesimpulan}

Berdasarkan kegiatan yang dilakukan penulis mulai dari tahapan proses observasi sampai tahap perancangan sistem, maka penulis memberi kesimpulan bahwa sistem informasi perpustakaan berbasis web ini sangatlah penting keberadaannya di Desa Pebayuran, dan beberapa kesimpulan antara lain adalah sebagai berikut.

1. Dengan Penggunaan sistem Informasi Perpustakaan berbasis web mempermudah petugas dan pengguna dalam peminjaman dan pengembalian buku pada perpustakaan Desa Pebayuran

2. Pengelolaan data perpustakaan khususnya peminjaman dan Pengembalian buku lebih tercatat dan mempermudah proses pemantauan stok buku di perpustakaan.
3. Anggota dapat mudah mengakses serta mengetahui tentang informasi buku termasuk stok buku yang tersedia tanpa perlu datang langsung ke perpustakaan desa Pebayuran

\section{Daftar Pustaka}

[1] Basuki Sulistyo, "Pengertian dan Fungsi Perpustakaan menurut Para Ahli," duniaperpustakaan.com, 2016. [Online]. Available:

https://duniaperpustakaan.com/2016/08/p engertian-dan-fungsi-perpustakaanmenurut-ahli.html. [Accessed: 06-Oct2021].

[2] J. Dermawan and S. Hartini, "IMPLEMENTASI MODEL WATERFALL PADA PENGEMBANGAN BERBASIS WEB PADA SEKOLAH DASAR AL-AZHAR SYIFA BUDI JATIBENING," Para, vol. 19, no. 2, 2017.

[3] D. S. Purnia, A. Rifai, and S. Rahmatullah, "Penerapan Metode Waterfall dalam Perancangan Sistem Informasi Aplikasi Bantuan Sosial Berbasis Android," 2019.

[4] S. C. Dewi, A. Saryoko, and H. S. Sukmana, "Perancangan Sistem Informasi Penerimaan Kas Pada PT. Andita Mas Bekasi," Paradigma, vol. XX, no. 1, pp. 70-77, 2018.

[5] D. Anggraeni, "Perancangan Sistem Informasi Akuntansi Penjualan dan Piutang Dagang Pada $C V$. Panen Raya Persada Pontianak," Repository.bsi.ac.id, vol. 53, no. 9, pp. 1-30, 2017.

[6] N. Alifah and A. Cahyo, "Analisis dan perancangan desain sistem informasi perpustakaan sekolah berdasarkan kebutuhan sistem," Berkah Ilmu Perpus. dan Inf., vol. 14, no. 1, 2018. 